\title{
Ostomy or intestinal anastomosis in cases of peritonitis
}

\author{
Emergency Service Of the Surgery Department, Santa Casa de São Paulo School of Medicine - São Paulo, Brazil
}

\begin{abstract}
Twenty-six patients showing peritonitis due to nontraumatic acute abdomen were submitted to ostomy. Mean age was 51 years (range 25-83), being 13 males and 13 females. Bowel obstruction (BO) was the most frequent cause of peritonitis (11 cases), followed by intestinal perforation (IP) (8 cases), acute mesenteric infarction (AMI) (5 cases), and acute abdomen of inflammatory / infectious origin (AAIO) (2 cases). Brook's ileostomy was performed on $65 \%$ of the patients. Jejunostomy was performed only in 4 patients, leading to a bad evolution. Overall mortality was $54 \%$. Primary ostomy or anastomosis in cases of peritonitis constitute a highly controversial theme. Indications and problems involving the intestinal exteriorization in emergency surgery urgency are herein discussed.
\end{abstract}

UNITERMS: Ostomy. Intestinal anastomosis. Acute abdomen. Peritonitis

\section{INTRODUCTION}

$\mathrm{T}$ he performance of ostomy or intestinal anastomosis in cases of peritonitis is a controversial theme in emergency surgery. On one hand there are risks of dehiscence, and on the other hand, the inconveniences of small bowel exteriorization, particularly in its most proximal portion.

The controversy increases when small bowel is involved, where in the colostomy to protect a suture or anastomosis when treating a wound is welldefined.

Ileostomy, which represents a perfectly tolerable ostomy without intercurrences, has always been an object of restriction for surgeons, particularly in emergency

\section{Address for correspondence:}

Samir Rasslan

Rua Marquês de Itú 837 / Sala 13

São Paulo/SP - Brasil - CEP 01223-001 surgery, although in peritonitis it has been practiced since the beginning of the century (8). More serious is the exteriorization of the more proximal segments, due to severe metabolic spoliation, with loss of great volumes of intestinal liquid.

Therefore, the suture or anastomosis in cases of peritonitis raise some fundamental questions such as:

a. Does it present a higher incidence of dehiscence?

b. What local changes lead to the suture failure?

c. Is it different according to the compromised viscera?

d. What is the inconvenience of ostomy?

The answers to these questions are not easy and not always supported by scientific data, as comparative studies of the diseased population are not feasible. They reflect, therefore, mostly the experience of surgeons. Nevertheless, studies have demonstrated high incidence of anastomosis dehiscence in cases of peritonitis or sepsis $(6,13,14)$.

In view of the interest this theme raises and its controversies, our report aims to analyze the use of ostomies in cases of peritoneal infection, evaluating the parameters that may direct the surgeon's decision. 


\section{MATERIAL AND METHOD}

From February 1990 to February 1993, 26 patients underwent ostomy due to nontraumatic acute abdomen complicated with peritonitis at the Emergency Service of the Santa Casa de São Paulo School of Medicine.

Mean age was 51 years, (range 25-83), being 13 male and 13 female. Forty-two percent of the patients showed bowel obstruction from different etiologies, requiring resection of the intestinal segment and exteriorization due to vascular acute abdomen. In the remaining cases ileostomy was performed.

Exteriorization of Brooke's terminal type occurred in 17 patients $(65 \%)$, two "stomas" in six patients $(23 \%)$ and loop ostomy in three patients (12\%) - (Table 3 ). Twenty-three of these patients were submitted to ostomy during the first procedure and three during re-operation for treatment of complications.
TABLE 1

Causes of Acute Abdomen

\begin{tabular}{lc}
\hline SYNDROME & No. OF CASES (\%) \\
\hline BO & $11(42 \%)$ \\
IP & $8(31 \%)$ \\
AMI & $5(19 \%)$ \\
AAIO & $2(8 \%)$ \\
TOTAL & $26(100 \%)$ \\
\hline
\end{tabular}

\section{RESULTS}

Mortality in the immediate and early postoperative period (mean of 20 days, ranging from 1 to 122 days)

TABLE 2

Etiology of Acute Abdomen with Peritonitis

\begin{tabular}{|c|c|}
\hline B O & $\begin{array}{l}\text { Incarcerated hernia } 4 \\
\text { Adhesions } 3 \\
\text { Transverse Colon tumor } 1 \text { (complicated with ischemia as far as ileum) } \\
\text { Rectal stenosis } 1 \text { (Duhamel-Haddad p.o. with ischemia as far as ileum) } \\
\text { lleal Stenosis } 1\end{array}$ \\
\hline IP & $\begin{array}{l}\text { Ileal perforation by tuberculosis } 2 \\
\text { lleal perforation in HIV }+2 \\
\text { lleal Tumor } 2 \\
\text { lleal perforation by Crohn's Diase } 1 \\
\text { Cecal perforation } 1\end{array}$ \\
\hline $\mathrm{AMI}$ & $\begin{array}{l}\text { Thrombosis of mesenteric artery } 1 \\
\text { Thrombosis of mesenteric vein } 1 \\
\text { Non-oclusive mesenteric insufficiency } 2\end{array}$ \\
\hline AAIO & $\begin{array}{l}\text { Terminal ileal tumor } 1 \\
\text { Enteric fistula (anastomosis dehiscence) } 1\end{array}$ \\
\hline
\end{tabular}

$\mathrm{B} \mathrm{O}=$ Bowel obstruction

I $\mathrm{P}=$ Intestinal perforation

$A M I=$ Acute mesenteric infarction

$A A I O=$ Acute Abdomen of inflammatory or infectious origin 
occurred in 14 patients $(54 \%)$, all directly related to the acute illness.

The rate was $80 \%$ for the patients with AMI (4 in 5), $45 \%$ with BO (5 in 11), $50 \%$ with IP (4 in 8 ) and of $50 \%$ with AAIO (1 in 2). There were no survivors in the group submitted to jejunostomy (Table 4).

Transit reconstruction was performed on 6 of the 12 survivors. Among the patients not submitted to reconstruction, 2 had AIDS (Acquired Immunodeficiency Syndrome) and were referred to specific hospitals, 2 are expecting re-hospitalization and abandoned the followup.

Tolerance to ostomy was satisfactory, with no significant metabolic effects, repercussions or local changes in the abdominal wall. Reconstruction was always performed three months after the postoperative period.

\section{DISCUSSION}

Anastomotic dehiscence is the main cause of morbidity and mortality in intestinal resections, especially colorectal, with rates of up to $30 \%(2,7,12)$.

Our analysis excludes the infections from large bowel lesions in which there are few doubts as to the use of ostomies. Primary colon anastomosis is an uncommon procedure (which can only be applied in selected cases), and colostomy does not raise inconveniences from the metabolic point of view.

On the other hand, ileum exteriorization is performed with caution, and terminal jejunostomy is rarely considered. Most of the time the risk of a high jejunal anastomosis dehiscence is preferred to the metabolic disturbances raised by ostomy. In this way, , surgeons often try intestinal sutures or anstomosis in patients with poor general conditions, or in re-operations with dehiscence and severe peritoneal contamination (4).

In peritoneal infection, even when the theoretical aspects and principles are respected by the surgeon, such as good irrigation, adequate border coaptation, and tension and the absence of disease, dehiscence may occur due to other systemic or local factors (2).

The role played by the intra-cavity infection has been studied experimentally and seems to determine biochemical disturbances explained by a collagen synthesis and activity reduction $(6,1,9)$. It is generally accepted that infection or bacterial contamination determines the collagen lysis increase by stimulating the colon submucosa collagenasis. $(6,12)$. Dunphy (1) demonstrated in animals that the bacterial growth in the anastomosis stimulates the collagen lithic activity, giving rise to changes in the suture tension, with failure of the anastomosis.

This has also been noticed by other authors (5).

The following parameters should be taken into consideration before a decision for primary ostomy or anastomosis is taken: portion of the digestive tract, severity of peritonitis, patient's general condition, etiology of infection, and others. Of all these, the most difficult to evaluate is the severity of peritonitis, which cannot be mathematically assessed, being subjective, and related to the surgeon's experience.

When the large bowel is involved, independently of the degree of peritonitis, the etiology of the infection and the patient's condition, the option for almost all cases is colostomy. Primary colon anastomosis is rarely performed in peritonitis cases. The surgeon may regret or even be criticized for having performed anastomosis, but this will never happen in the case of exteriorization. Not that anastomosis is a forbidden procedure, but it should be avoided, being reserved for special cases only if and when infection is not so severe. Our 26 patients were submitted to the small bowel exteriorization, terminal jejunostomy
TABLE 3

Types of intestinal exteriorization

\begin{tabular}{lc}
\hline EXTERIORIZATION & No. of Cases \\
\hline Brooke's Terminal & $17(65 \%)$ \\
Two Stomas & $6(23 \%)$ \\
Loop & $3(12 \%)$ \\
\hline Jejunostomy & $4(15 \%)$ \\
lleostomy & $22(85 \%)$ \\
\hline
\end{tabular}

TABLE 4

Postoperative Mortality

\begin{tabular}{ll}
\hline BO & $5(45 \%)$ \\
\hline IP & $4(50 \%)$ \\
\hline AMI & $4(80 \%)$ \\
\hline A I O & $1(50 \%)$ \\
\hline TOTAL & $14(54 \%)$ \\
\hline
\end{tabular}


CHART 1

Parameters for the performance of primary anastomosis or ostomy

\begin{tabular}{l|c|c|c}
\hline & $\begin{array}{c}\text { SEVERITY OF } \\
\text { PERITONITIS }\end{array}$ & $\begin{array}{c}\text { ETIOLOGY OF } \\
\text { INFECTION }\end{array}$ & $\begin{array}{c}\text { PATIENT'S } \\
\text { CONDITION }\end{array}$ \\
\hline OSTOMY & SEVERE & VASCULAR \\
& PURULENT & INTESTINAL \\
& STERCORAL & DIASE & \\
& & BNFLAMATORY \\
& & DIASE & \\
\hline PRIMARY & REOPERATION & \\
ANASTOMOSIS & NOT SEVERE & TRAUMA & \\
& CHEMICAL & & GOOD \\
& FIBRINOUS & MECHANICAL & \\
\hline
\end{tabular}

being performed only in four and ileostomy in the remaining.

Although there are no specific rules for the small bowel, it is possible to define them based on different parameters. The performance of ostomy is usually the rule, even in the small intestine, in patients with poor general conditions and severe compromising of the peritoneal cavity.

The etiology of the infection injection or the primary disease contribute to this decision. When the peritonitis is due to a primary vascular cause, which determines intestinal infarctions or necrosis, the decision should be taken towards exteriorization due to the risk of post operative - which cannot be characterized during the operation - resulting in a high rate of fistulas (11). In the presence of intestinal inflammatory disease with perforation and peritonitis, the option should also be ostomy (10), as the suture or anastomosis can be done in an affected area which, many times, the surgeon has no ability to assess macroscopically. Chart 1 is a suggestion to systematize the procedure adopted in our Emergency Service.

A correct evaluation of the intestine during the operation procedure is very difficult.

In spite of adequate irrigation, the edema and trophic changes of the intestinal wall, which are not visible, interfere with healing, contributing to the failure.
Another situation is when re-operation is indicated due to infection and anastomosis dehiscence. It is important to stress that if the suture was not effective in the first operation, when the patients conditions were more favorable, it is not likely to be effective in the second trial. The attempt to resuture depending on local conditions, can even worsen the dehiscence. In special situations, such as a gastroenteroanastomosis dehiscence, the surgeon can try to approximate the layers, being aware of the high probability of postoperative failure.

Mortality in our cases was extremely high (54\%), but in accordance with the population analyzed. No patient with proximal terminal jejunostomy survived, mostly in consequence of the primary disease - intestinal infarction - and probably not due to the enteric ostomy.

A new operation for transit reconstruction should not be performed before 12 weeks. This period of time is generally enough for the recovery, infection control and improvement of the local abdominal wall condition, negatively affected by the secretions rich in gastrintestinal enzymes

In case of doubt regarding the performance of a primary anastomosis, the surgeon should choose ostomy, as experience shows that mortality is lower when it is carried out during the first operation as compared to the second operation (3). 


\section{RESUMO}

São analisados 26 doentes submetidos à estomia na vigência de peritonite por abdome agudo não traumático. A faixa etária variou de 25 a 83 anos, com média de idade de 51 anos. Nāo houve predomínio quanto ao sexo. O abdome agudo obstrutivo (AAO) foi a causa mais freqüente de peritonite (11 casos), seguido do abdome agudo perfurativo (AAP) em 8 , abdome agudo vascular (AAV) em 5 e inflamatório (AAl) em 2. Na maioria dos doentes (65\%) foi realizada ileostomia à Brooke. Em apenas 4 praticou-se a jejunostomia, observando-se má evoluçāo. A mortalidade global foi de $54 \%$. A realização de estomia ou anastomose primária na presença de peritinite constitui um tema com muitas controvérsias. Neste artigo são discutidas as indicaçōes e os problemas envolvendo a exteriorização intestinal na urgência.

\section{REFERENCES}

1. DUNPHY, J.E - The cat gut. Am J Surg. 119: 1, 1974.

2. GENZINI. T.; D'ALBUQUERQUE, L.A.C.; MIRANDA, M.P.; SCAFURI, A.G. \& SILVA. A.O. - Intestinal anastomosis. Rev Paul Med. 110:183,1992.

3. GONÇALVES, A.J. - A utilização das ileostomias na cirurgia de urgência. Dissertação de Mestrado. Faculdade de Ciências Médicas da Santa Casa de São Paulo, 1985.

4. GONÇALVES, A.J. \& RASSLAN, S. - Ileostomias: uma alternativa na cirurgia de urgência. In Rasslan, S. - Aspectos "críticos" do doente cirúrgico. São Paulo, Robe Ed. 1988. p. 247.

5. HAWLEY, P.R.; PAGEFAUlK, W. \& HUNT, T.K. Collagenase activity in the gastrintestinal tract. Br J Surg. $\mathbf{5 7 : 8 9 6 , 1 9 7 0 .}$

6. IRVIN, T.T. - Collagen metabolism in infected colonic anastomosis. Surg Gynecol Obstet. 143:220, 1976.

7. KHOURY, G.A. \& WAXMAN. B.P. - Large bowel anastomosis. The healing process and sutured anastomosis. A review. Br J Surg. 70:1983.
8. LUND, F.N. - The value of enterostomy in selected cases of peritonits. JAMA. 41:74, 1993.

9. NIINIKOSKI, J. \& GRILIS HUNT, T.K. - Respiratory gas tensions and collagen in infected wounds. Ann Surg. 175:588, 1972.

10. RASSLAN, S.; KLUG, W.A.; MANDIA NETO. J.; FAVA, J.; SAAD JR, R. \& GONÇALVES, A..J. - Tuberculose intestinal complicada. Rev Assoc Med Brasil. 30:39, 1984.

11. RASSLAN, S.; MANDIA NETO, J. \& FAVA, J. - Fístulas intestinais após ressecções extensas de delgado. GED. 4:17, 1985 .

12. RAVO, B. - Colorrectal anastomotic healing and intracolonic bypass procedure. Surg Clin North Am. 68: 1267, 1988.

13. SCHROCK, T. R.; DEVENCY, C.W. \& DUNPHY, J.E. Factors contributing to leakage of colonic anastomosis. Ann Surg. 177:513, 1973.

14. YAMAKAWA, T.; PATTIN, C.S.; SOBEL, S. \& MARGENSTERN, L. - Healing of colonic anastomosis following resections for experimental diverticulitis. Arch Surg. 103: 17, 1971. 